\title{
Dijital Oyunları İleri Yaşlı Bireylerin Bilişsel İşlevlerini Artırır Mı?
}

\section{Can Digital Game Play Improve Older Adults' Cognitive Skills?}

\author{
İlmiye Seçer ${ }^{1} \odot$
}

'Öğr. Gör. Dr., Başkent Üniversitesi, Fen-Edebiyat Fakültesi, Psikoloji Bölümü, Ankara, Türkiye

ORCID: I.S. 0000-0002-0119-0075

\section{Sorumlu yazar/Corresponding author:} İlmiye Seçer,

Başkent Üniversitesi Fen-Edebiyat Fakültesi, Bağlıca Yerleşkesi, Eskişehir Yolu 18. km. Etimesgut, 06790 Ankara, Türkiye

E-posta/E-mail: secer.ilmiye@gmail.com

Başvuru/Submitted: 21.04.2020

Kabul/Accepted: 07.09.2020

Online Yayın/Published Online: 24.02.2021

Citation/Atıf: Secer, I. (2021). Dijital oyunları ileri yaşlı bireylerin bilişsel işlevlerini artırır mı? Psikoloji Çalışmaları - Studies in Psychology, 41(1): 35-60.

https://doi.org/10.26650/SP2020-0050
ÖZ

Bilişsel süreçler, kendi başına yemek yiyebilmek, kişisel bakım ve ilaç/ para idaresinin yapılabilmesine kadar pek çok basit ya da kompleks günlük yaşamsal aktivitelerde önemli bir rol oynamaktadır. Artan yaşla birlikte bilişsel yeteneklerdeki düşüş, yaşlı yetişkinlerin toplumda bağımsız kalma becerilerini engeller ve yaşam kalitelerini olumsuz yönde etkiler. Bu nedenle bir dizi çalışma, bu tür becerileri sürdürebilecek ve etkili bir şekilde geliştirebilecek yolları araştırmaktadır. Dijital oyunlar farklı yaştaki bireyler tarafından tercih edilen boş vakit geçirme aracı haline gelmiştir. Ayrıca, eğlence, stres atma gibi birçok amaçla da oynanabilmektedir. Bu bağlamda, kolay erişebilir ve eğlenceli olmalarından dolayı ileri yaştaki bireylerin sıklıkla tercih ettiği dijital oyunların bilişsel süreçlerini iyileştirip iyileştirmediği dikkat çekici bir araştırma konusudur. Alan yazında yer alan araştırmaların bulguları genelde dijital oyun oynamanın tepki süresini, çalışma belleğini ve görev değiştirme gibi becerileri geliştirdiğini göstermektedir. Ancak, dijital oyun oynamanın etkili bir bilişsel egzersiz rejimi olduğunu iddia etmeden önce araştırılması gereken konular vardır. Bu aşamada, mevcut çalışma, ileri yaştaki bireylerde dijital oyunların etkinliğinin sınanmasına yönelik bir derleme olup, dijital oyunların bilişsel avantaj getirisinin olup olmadığı incelenmiş, gelecek çalışmalar için araştırma önerilerinde bulunulmuştur. Örneğin, uzak transfer etkisinin diğer bir değişle, bu etkilerin günlük aktivitelerin de daha iyi yapılabilmesine neden olup olmadığını ve gelişen bilişsel becerilerin uzun süre korunabilmesini sağlayan koşulların neler olduğu açıklama bekleyen sorulardır. Ayrıca, dijital oyunların ekolojik geçerlik ve herhangi bir zihinsel faaliyetten farklı bir getirisinin olup olmadığının araştırılması gerekmektedir. Ayrıca, daha önce Boot, Blakely ve Simons (2011) ve Boot, Simons, Stothart ve Stutts (2013) tarafindan ortaya konulan öneri; plasebo etkilerinin göz önünde bulundurulmasının önemi, vurgulanmıştır.

Anahtar Kelimeler: Dijital oyunlar, bilişsel işlevler, ileri yetişkinler 


\section{ABSTRACT}

Cognitive skills are essential for the performance of basic and instrumental daily living activities such as self-care, medication, and finance management. A decline in cognitive abilities with increasing age thus hinders older adults' ability to remain independent in society and negatively influences their quality of life. Therefore, many studies have investigated ways that can maintain and effectively improve such skills. Digital games have become a favored leisure activity by all age groups and are played for entertainment and stress relief. In this context, the ease with which digital games can be played within the home and their entertaining nature have led researchers to examine their effectiveness in enhancing older adults' cognitive skills. Although the findings indicate cognitive advantages, such as improved reaction times, working memory, and task-switching abilities, many questions require further clarification before claiming that digital game play is an effective cognitive training regime. Therefore, the current review aims to examine the cognitive advantages of digital games for older adults and suggests future research directions. The following topics need to be further explored: the existence of far transfer effects, that is, whether such improvements lead to better performance of daily activities, the long-term maintenance of enhanced skills and the underlying responsible mechanisms, the ecological validity of digital games, and digital games' provision of benefits beyond cognitive simulations. Furthermore, the importance to consider placebo effects, which was suggested by Boot, Blakely, and Simons (2011) and Boot, Simons, Stothart, and Stutts (2013), is emphasized.

Keywords: Digital games, cognitive skills, older adults

\section{EXTENDED ABSTRACT}

In Turkey, as in worldwide, digital games ${ }^{1}$ have become a favored leisure activity (Baran, Kurt, \& Tekeli, 2017; Becerikli, 2013; Karakuş, Inan, \& Çağıltay, 2008; Kaşıkçı, Çağıltay, Karakuş, Kurşun, \& Ogan, 2014; Şahin, 2019) and are played to relieve stress and for entertainment (Gökkaya \& Deniz, 2014; Karakuş et al., 2008; Uluyol, Demiralay, Şahin, \& Eryilmaz, 2014; Yavuz \& Tarlakazan, 2018). In addition to the social aspects of video game play, much interest has been paid to determining whether digital game play can be a form of cognitive training, particularly to enhance older adults' cognitive skills that decline as age increases (Cangöz, 2017). Cognitive skills are related to older adults' (65+ years $\left.{ }^{2}\right)$ basic daily living activities (e.g., ability to eat independently and self-care) (Tuncay \& Fertelli, 2018) and instrumental activities (e.g., medication and finance management) (Bell-McGinty, Podell, Franzen, Baird, \& Williams, 2002; Cahn-Weiner, Boyle, \& Malloy, 2002). Investigating methods to enhance cognitive skills has thus become vital. The current paper aims to review past studies that have examined video games and cognitive skills among older adults and determine research areas that require further investigation.

1 Digital games (video games) are inclusive of digital games played on all platforms (e.g., PC, console, tablet, and mobile) that include a story or visual modality (Güvenli İnternet Merkezi, 2019). Past studies that have researched the effects of commercial games or those played over the internet have been included in this review. However, studies investigating the effects of computerized cognitive training have been excluded.

2 Some studies (e.g., Dustman et al., 1992) include older adults aged 60+ years. 
Concerning digital game play and cognitive skills in older adults, initial experimental studies (Clark, Lanphear, \& Riddick, 1987; Dustman Emmerson, Steinhaus, Shearer, \& Dustman, 1992; Goldstein et al., 1997) revealed that video game play improves reaction times among older adults. Furthermore, Basak, Boot, Voss, and Kramer (2008), who required older adults to play Rise of Nations for 23.5 hours (Big Huge Games, 2004), in their study, revealed improved skills of mental rotation, visual short-term memory, and task switching. Conversely, other studies find no effect in reaction times (Huseyin \& Satyen, 2009), attention (Nouchi et al., 2012), divided attention, and encoding and retrieval processes (Huseyin \& Satyen, 2009). Further investigation is needed to determine whether confounding factors such as the rate of cognitive decline account for the mixed findings. Further research is also required to discern the conditions that can lead to long-term effects of video game play.

\section{Discussion}

Past findings (e.g., Basak et al., 2008; Clark et al., 1987; Dustman et al., 1992) have shown improved cognitive skills among older adults following video game play, which agree with the cognitive training framework in which practical skills are enhanced. However, whether the digital game play is solely accountable for such improvements or the result of any cognitive simulation is debatable, requiring further clarification.

One way to discern the cognitive effects of video game play is to rule out the placebo effects (Boot, Blakely, \& Simons, 2011; Boot, Simons, Stothart, \& Stutts, 2013). Boot et al. (2011) and Boot et al. (2013) suggested the importance to equate groups on their awareness of the connection between cognition and game play, and the motivation to participate in the experiment. To the best of the author's knowledge, this has not been effectively researched among older adults.

Considering that one aim of enhancing older adults' cognitive skills is to improve their quality of life, such improvements must be transferred to daily activities (e.g., driving ability) and protected against the negative effects of cognitive aging such as increased falls and fall-related injuries (Liu, Chan, \& Yan, 2014; Muir, Gopaul, \& Odasso, 2012). There is however a dearth of research showing ecological validity. The impact of video games on mild cognitive impairment ( $\mathrm{MCl}$ ) and Alzheimer's Disease (AD) must be determined further. In Turkey, Cangöz, Çağıltay, Özel Kızıl, Oktay, and Özcan (2017) (as cited in Cangöz, 2018) have developed a program to assess the effect of computerized games on the cognitive abilities of individuals with normal cognitive decline, $\mathrm{MCl}$, and AD. After 88 hours of computerized game play, preliminary results have shown that the neuropsychological test scores remained constant. The effectiveness of such a program on delaying the progression of $\mathrm{MCl}$ and $\mathrm{AD}$ symptoms is deemed important for cognitive rehabilitation purposes. 
Overall, the effect of video game play on older adults' cognitive skills is a current research topic. The ease with which such games can be accessed and their entertaining nature render them an effective cognitive training method. However, further studies should focus on ruling out motivational effects and demonstrate the effects outside the laboratory that transfer to daily activities. 
Dünyada olduğu gibi, Türkiye'de de dijital oyunlar ${ }^{1}$ yediden yetmişe oynanmakta olup (Baran, Kurt ve Tekeli, 2017; Becerikli, 2013; Karakuş, Inan ve Çağıltay, 2008; Kaşıkçı, Çağıltay, Karakuş, Kurşun ve Ogan, 2014; Şahin, 2019) giderek daha fazla tercih edilen bir stres atma, eğlenme ve boş vakit geçirme yöntemi haline gelmiştir (Gökkaya ve Deniz, 2014; Karakuş ve ark., 2008; Uluyol, Demiralay, Şahin ve Eryilmaz, 2014; Yavuz ve Tarlakazan, 2018). Dijital oyunlara rağbet arttıkça, oyunların psikolojik zararları ve yararları araştırmalara konu olmaya başlamıştır. Bu çalışmaların sonuçları, şiddet içerikli dijital oyunlar ile saldırganlık davranışlarının ilişkili olduğunu (Anderson ve Bushman, 2001; Bayraktar ve Gün, 2007) ve fazla oyun oynamanın özsaygıda azalma gibi negatif psikolojik etkilerinin olduğunu göstermiştir (Kirby, Jones ve Copello, 2014; von der Heiden, Braun, Müller ve Egloff, 2019). Diğer yandan, makul seviyelerde dijital oyun oynamanın sosyal dayanışma, yalnızlık hissinin azalması, mutluluk, yaşam doyumu ve psikolojik iyilik ile ilişkili olduğu bulunmuştur (Balkan ve Adalier, 2011; Goldstein ve ark., 1997; Kahlbaugh, Sperandio, Ashley, Carlson ve Hauselt, 2011; Jones, Scholes, Johnson, Katsikitis ve Carras, 2014).

Psikolojik etkilerinin yanı sıra oyun oynamak zihnimiz için bir egzersiz olup bilişsel süreçleri, özellikle de yaşlanmadan dolayı azalan bilişsel işlevleri (Cangöz, 2017) iyileştirip iyileştiremediği sıkça araştırılan konular arasındadır. Bilişsel işlevler, ileri yaştaki (65 yaş ve üstü²) bireylerin yaşam doyumu ve günlük yaşam aktiviteleri, örneğin kendi başına yemek yiyebilmek ve kişisel bakımını yerine getirebilmek gibi basit davranışlar (Tuncay ve Fertelli, 2018), ya da kendi ilaçlarını alabilmek veya paralarını idare edebilmek gibi daha karmaşık davranışlar ile ilişkilidir (Bell-McGinty, Podell, Franzen, Baird ve Williams, 2002; Cahn-Weiner, Boyle ve Malloy, 2002). Bu ilişki göz önünde bulundurulduğunda bilişsel süreçlerinin iyileştirilmesinin ve bu iyileşmeyi sağlayacak yöntemlerin araştırılmasının önemi artmaktadır.

Beynin çevre ile iletişimi sonrasında uyumlanması (Held, 1965) ve tekrarlanan becerilerin gelişmesini sağlayabilmesi (Zelinski ve Reyes, 2009) beyin plastisitesi olarak adlandırılır ve sinir ağlarının değişmesi, güçlenmesi veya yeni ağların oluşması (Bavelier,

1 Dijital oyunlar (video games) tüm dijital ortamlarda (PC, konsol, tablet, mobil vs.) oynanabilecek metin ya da görsel üzerine inşa edilmiş oyunları kapsamaktadır (Güvenli İnternet Merkezi, 2019). Bu yazıda yer alan çalışmalar ticari amaçla satılan veya internet üzerinden oynanabilecek dijital oyunları ele almıştır. Bilişsel işlevlerine yönelik bilgisayarlı egzersiz çalışmalarını içermemektedir.

2 Bazı araştırmalar, (örn., Dustman, Emmerson, Steinhaus, Shearer ve Dustman, 1992) 60 yaş ve üstü olan bireyleri ileri yetişkinler grubuna dahil etmiştir. 
Levi, Li, Dan ve Hensch, 2010; Cai, Chan, Yan ve Peng, 2014; DeFelipe, 2006) söz konusudur. Bu doğrultuda, tekrar tekrar oynanması sayesinde dijital oyunların beyin plastisitesine yol açabilecek bir aktivite olduğu düşünülüyor. Oyunların yapılarını inceleyerek nasıl tekrarla oynanabildiklerini anlayabiliriz. Dijital oyunlar ekrandaki görsel uyarıcılara joystick, klavye veya diğer cihazlarla, örneğin direksiyon ile yanıt verilmesini içerir. Oyunun gerektirdiği görevlerin doğru tamamlanması ödüllerin kazanılmasına veya çoğunlukla daha zor olan bir üst tura geçilmesini sağlarken, hata yapılması puan kaybına veya aynı turun tekrarlanmasına sebep olur. Aynı turun tekrarlanması, hatalardan ders çıkarmaya ve yeni stratejiler geliştirmeye imkan tanır (Zelinski ve Reyes, 2009). Bu doğrultuda, dijital oyunların eğlenceli ve motive edici olmaları uzun süreli oynanabilir olmalarına neden olur (Zelinski ve Reyes, 2009). Bunun yanında, oyunların gerektirdiği bilişsel becerilerin sürekli pratik ettirilmesiyle bu becerilerin gelişmesi de söz konusudur. Oyun oynama ile beyin plastisitesi arasındaki ilişki, sinirbilim çalışmalarından elde edilen bulgular ile de desteklenmektedir. Dijital oyun oynayan (örn., Super Mario 64) (Nintendo VC, 2006) ileri yetişkinler grubunun hipokampus, dorsolateral prefrontal korteks ve beyincik beyin bölgesindeki gri madde hacimlerinin daha fazla olduğu bulunmuştur (West ve ark., 2017).

Dijital oyunların diğer bilişsel egzersizle olan avantajı evlerde kolaylıkla erişilip, hoş vakit geçirerek oynanabilmeleridir (American Association of Retired Persons, 2019). İleri yetişkinlere böyle bir yöntemi önermeden önce, dijital oyunların bilişsel süreçler üzerinde etkili olup olmadığını bilmek önemlidir. Dolayısıyla, bu yazının amacı dijital oyunların bilişsel yaşlanmadan koruyup korumadığını incelemek ve bu alanda hala yanıtlanması gereken sorulara (örn., bilişsel işlevlerin korunabilmesi için ne kadar süre oyun oynanması gerektiği veya uzak transferin olup olmadığı) değinmektir.

\section{Dijital Oyunlar ve İleri Yetişkinlerin Bilişsel İşlevleri}

Dijital oyunların ileri yetişkinlerin tepki süresi, çalışma belleği ve yönetici işlevleri gibi bilişsel işlevlerindeki performansı artırıp artırmadığ 1 birçok araştırmacı tarafından (Basak, Boot, Voss ve Kramer, 2008; Clark, Lanphear ve Riddick, 1987; Dustman ve ark., 1992) incelenmiştir. Bu bölümde bu araştırmalar gözden geçirilecektir.

\section{Dijital Oyunların İleri Yetişkinlerdeki Tepki Süresine Etkisi}

Tepki süresi, beynin bir bilgiyi ne kadar hızlı işlediğinin göstergesidir ve çevresel uyaranlara ne kadar hızlı yanıt verdiğimizle ölçülür (Salthouse, 2000). Örneğin trafikte 
kırmızı 1şı̆̆ın yeşile dönmesi ile bireyin aracını hareket ettirmesi arasındaki zaman farkı tepki süresini verir. Laboratuvar ortamında tepki süresi, tepki süresi görevleri ile ölçülür. Bu görevlerde birey, ekrandan görülen bir uyarana önceden belirlenmiş tuşa basarak tepki verir. Tepki süresi ise uyaranın ekranda görülme zamanı ile verilen tepki arasında geçen zamana verilen isimdir ve milisaniye olarak değerlendirilir (Dearly, Liewald ve Nissan, 2011; Perez, Izura, Stadthagen-Gonzanes ve Marín, 2013; Whelan, 2008).

İki tür tepki süresi görevinden bahsedilebilir. Bunlar basit görevler ve seçmeli görevlerdir. Basit tepki süresi görevinde tek bir uyaran ile örtüşen tek bir tepki vardır, seçmeli tepki süresi görevlerinde ise birden fazla uyaran ve her bir uyarana eşleşen ayrı bir tepki seti vardır (Palef, 1973). Bu basit, iki seçmeli ya da dört seçmeli görevlerde uyaran-tepki sayısı arttıkça görev talepleri artar. Dolayısıyla, görevi yerine getirebilmek için ketleme, çalışma belleği gibi daha fazla bilişsel kontrole ihtiyaç duyulur (Cepeda, Blackwell ve Munakata, 2013). Uyaranlar söz konusu olduğunda seçenek sayısı arttıkça bireylerin daha yavaş tepki verdikleri görülmekte olup (Fletcher ve Rabbitt, 1978; Mowbray, 1960; Mowbray ve Rhoades, 1959), bu durumun bilgiyi işleme (uyaranı algılama, doğru tepki setinin etkinleşmesi ve doğru kararın seçilmesi) ile motor tepkinin verme süresiyle bağlantılı olduğu düşünülmektedir (Botwinick ve Thompson, 1966).

Tepki süresini etkileyen faktörlerden birisi de yaştır. Bireyin yaşı arttıkça hızlı tepki verebilme becerisinin yavaşlamakta olduğu gösterilmektedir (Myerson, Robertson ve Hale, 2007). İleri yetişkinlerin özellikle seçmeli tepki zamanı görevlerinde genç bireylere göre daha yavaş tepki verdiği bulunmuştur (Ratcliff, Thapar ve McKoon, 2006). Bu durumun bilişsel kontrol, gereksiz bilgiyi göz ardı edebilme ve doğru yanıtı seçebilme süreçlerinde zorlanılmasından kaynaklandığı düşünülmektedir (Stuss, Stethem, Picton, Leech ve Pelchat, 1989). İlerleyen yaşla birlikle azalan tepki verebilme becerisinin nasıl gelişebileceğini araştırmak oldukça önemlidir. Ayrıca, ileri yetişkinlerde düşme ve düşmeden kaynaklı yaralanmalar ciddi bir sorundur ve hızlı tepki verebilme davranışı ile olumsuz ilişkilidir (Lajoie ve Gallagher, 2004), bu da tepki verme süresi yavaşladıkça düşme ve düşmeden kaynaklı yaralanmaların artmakta olduğunu gösterir.

Tepki Süresi ve Dijital Oyunlar. Dijital oyunların biliş üzerindeki etkilerini araştıran ilk deneysel çalışmalar dijital oyun oynamanın ileri yetişkinlerin tepki hızını arttırdığını bulmuştur (Clark ve ark., 1987; Dustman ve ark., 1992; Goldstein ark., 1997). Benzer şekilde farklı oyunlarla da (örn., Pac-Man (Namco, 1980b) ve Donkey Kong (Clark ve 
ark., 1987; Nintendo, 1981), Breakout (Atari Inc.,1976), Galaxian (Namco, 1980a), Frogger (Konami, 1981), Kaboom! (Activision, 1983), Ms. Pacman (General Computer Corporation, 1982), Pengo (Coreland, 1982), Qix (Dustman ve ark., 1992; Taito, 1981), Super Tetris (Sphere Inc., 1991) (Goldstein ve ark., 1997) bulunmuştur. Ayrica, oyun oynama süreleri; 14 saat (Clark ve ark., 1987), 25 saat (Goldstein ve ark., 1997) ve 33 saat (Dustman ve ark., 1992) ile tekrarlandığında da bu bulgulara ulaşılmıştır.

Bu konuda yapılan bir çalışmada, Clark ve arkadaşları (1987) ileri yetişkinleri deney ve kontrol farklı gruplarına atayıp, deney grubundaki katılımcıların haftada en az iki saat, toplamda yedi hafta boyunca iki farklı dijital oyun oynamaları istemiştir³. Bu süre zarfında kontrol grubundaki bireyler oyun oynamamıştır. Tepki süresi görevinde bireylerin iki ışıktan birisinin yanması ile o ışıkla eşleşen tuştan parmağını kaldırması istenmiştir. Işı̆̆ın yanma süresi ile bireyin parmağının tuştan çekmesi arasındaki geçen zaman tepki süresi olarak kabul edilmiştir. Tepki süresi iki seçmeli tepki süresi görevi ile iki ayrı mekânsal uyaran-tepki koşulunda, uyumlu ve uyumsuz, ölçülmüştür. Uyaran-tepki uyumlu koşulda (stimuli-response congruent condition) uyaran ile tepki tuşu mekânsal olarak aynı, uyumsuz koşulda (incongruent condition) ise farklıdır. Örneğin uyaran-tepki uyumlu koşulda uyaran sağda ise katılımcının basması gereken tuş da sağ taraftayken uyumsuz koşulda uyaran, solda ise tepki tuşu sağda bulunmaktadır. Bu uygulama bilgi işleme modeline göre tepki seçme sürecinin ölçülmesini sağlar. Eğer, dijital oyunlar tepki seçme sürelerini olumlu etkiliyor ise deneysel gruptaki bireylerin uyumsuz koşuldaki tepki sürelerin azalması beklenmektedir. Clark ve arkadaşlarının (1987) deney bulguları deney beklentilerini destekler niteliğindedir. Gruplardaki bireylerin ön testteki tepki süreleri iki uyaran-tepki koşulunda birbirine denk olmasına rağmen, son-testte deney grubundaki bireylerin tepki süreleri iki koşulda da azalmıştır. Ön testteki uyumsuz uyaran-tepki koşulunda iki grup benzer şekilde olumsuz etkilenirken, son-testte oyun oynayan grup daha az etkilenmiştir (Clark ve ark., 1987). Bu bulgular dijital oyunların tepki seçme süresini olumlu etkilediğini, dijital oyun oynayan katılımcıların uyaran-tepki setini kısa süreli bellekte tutabildiğini ve etkin bir biçimde tepki seçimlerini yapabildiğini göstermektedir.

Benzer şekilde, Dustman ve arkadaşları (1992) toplamda 33 saat oyun oynamanın ileri yetişkinlerin tepki süresi üzerindeki etkisini araştırmıştır. Bireyler dijital oyun oynama grubu, film grubu ve kontrol gruplarından birisine seçkisiz atanmış; tepki süreleri

3 Bireyler tek bir oyun veya her ikisini de oynama seçeneğine sahipti. 
deneysel manipülasyon öncesinde ve sonrasında ölçülmüştür. Tepki süresini ölçmek için katılımcılara öncelikle bir, iki veya dört harften oluşan bir harf dizisi gösterilmiş, ardından katılımcılardan hedef bir harfin bu dizinin içinde olup olmadığını belirtmeleri istenmiştir. Hedef harf dizinin içerisinde bulunuyorsa birey sol eli ile bir düğmeye basmış, bulunmuyor ise sağ eli ile başka bir düğmeye basmıştır. Deney bulguları, tepki sürelerinin ön teste farklı olmamasına rağmen, son testte dijital oyun oynayan grubun diğer iki gruba kıyasla tepki süresinin daha kısa olduğunu göstermektedir. Bu bulgular, beynin bir görsel uyaranı algılamasıyla motor korteksin tepkiyi başlatması arasında geçen sürenin oyunlar sayesinde kısaldığına işaret etmektedir. Yönetici işlevler diğer bilişsel süreçler söz konusu olduğunda gruplar arası fark olmaması, dijital oyunlar ile tepki süresi görevlerini gerektiren becerilerin (değişen görsel uyaranlara hızlı motor tepki verme) örtüşmesi sayesinde tepki süresinin kısaldığını göstermektedir.

Dijital oyun oynamanın olumlu etkileri güncel çalışmalar tarafından da desteklenmektedir. Örneğin Ballesteros ve ark. (2014), bir grup ileri yetişkini deney ve aktif kontrol grubuna atayıp, deney grubundaki bireylere genellikle hız, tanıma ve eşleştirme becerilerini gerektiren Lumosity ${ }^{4}$ (Sarkar, Scanlon ve Drescher, 2007) oyununu 20 saat boyunca oynatmıştır. Tepki verme süresi basit ve iki seçmeli zaman görevi ile ölçülmüştür. Bu çalışmaların bulgularına göre her iki grubun tepki süreleri ön testte birbirine yakınken, sadece iki seçmeli görevde dijital oyun oynamanın tepki süresini azalttığ1 görülmektedir. Lumosity (Sarkar ve ark., 2007) oyunlarından biri olan ve iki seçenek arasında hızlı seçim yapma pratiği yaptıran Hızlı Eşleştirme isimli alt oyun, iki seçmeli tepki zamanı görevinde bireylerin daha hızlı tepki vermelerini sağlamıştır. Lumosity (Sarkar ve ark., 2007) oyunları arasında tespit etme ve yanıt verme pratiği yaptıran bir alt oyun olmaması, basit tepki zamanı görevindeki tepki süresinin neden azalmadığını açıklamaktadır. Daha az karmaşık olan ve bilişsel kontrol gerektirmeyen işlevlerin gelişiminin ne kadar mümkün olabileceği gelecek çalışmalar tarafından araştırmalıdır.

Dijital oyunların ileri yetişkinlerin tepki verme süreçlerini geliştirmesi, zihinsel egzersiz ile beyin arasındaki bağı ortaya koymakta büyük bir rol oynamaktadır. Bu çalışmalarda pasif ${ }^{5}$ (Clark ve ark., 1987; Goldstein ve ark., 1997) ve aktif ${ }^{6}$ kontrol gruplar1 (Dustman ve ark., 1992) kullanıldığında bile aynı sonuçlara varılması önemlidir. Böylelikle tepki verme sürelerinin azalması, özellikle de aktif kontrol grubunun olduğu çalış-

4 Birçok farklı oyunları kapsıyor örneğin hız eşleştirme veya yüz tanıma gibi

5 Katılımcıların hiçbir yapılandırılmış aktivite de yer almamaları istenilen grup

6 Katılımcıların farklı bir aktivite; örneğin film izleme yapması istenilen grup 
malarda, bunun oyun oynamadan kaynaklı olduğunu daha güçlü bir şekilde ortaya koyabilmektedir. Aksi takdirde tepki verme süresinin yinelenen testlerden veya herhangi bir başka aktivitenin etkisiyle kısalmış olabileceği düşünülmektedir.

Olumlu etkilerinin yanı sıra bazı çalışmalar, dijital oyunların ileri yetişkinlerin tepki verme sürelerini etkilemediğini bulmuştur (Huseyin ve Satyen, 2009). Huseyin ve Satyen (2009) tarafından yapılan bir çalışmada ileri yetişkinler deney ve kontrol gruplara rastgele atanmış, deney grubundaki bireyler üç saat Pac-Man: Adventures in Time (Mind's Eye Production, 2000) oyununu oynamıştır. Deneysel manipülasyon öncesi ve sonrası her iki grubun tepki süreleri dört seçmeli tepki süresi görevi ile ölçülmüştür. Diğer çalışmaların bulguların aksine, buradaki bulgular dijital oyun oynamanın tepki süresinin kısaltmadığını bulmuştur. Mevcut çalışmada (Huseyin ve Satyen, 2009) daha zor olan ve daha fazla bilişsel kontrol gerektiren dört seçmeli tepki zamanı görevinin kullanılması, bu çalışmayı diğer çalışmalardan (Ballesteros ve ark., 2014; Clark ve ark., 1987) ayıran bir değişkendir. Dört seçmeli tepki süresi görevi daha fazla çalışma belleğine ihtiyaç duymaktadır, bellekte tutulması gereken daha fazla uyaran-tepki seti vardır ve doğru yanıtın seçilebilmesi için daha fazla seçeneğin engellenmesi gerekmektedir. Bu becerilerin ileri yaşlarda önemli bir oranda gerilediğini göz önünde bulundurduğumuz zaman, üç saat oyun oynamanın bu becerileri geliştirmek adına yetersiz olabileceği olasıdır. Ayrıca, seçilen oyundaki beceriler ile daha karmaşık olan dört seçmeli tepki zamanı görevinde gerekli becerilerin ne kadar örtüştüğü oldukça tartışlabilir bir durumdur.

\section{Dijital Oyunların İleri Yetişkinlerde Çalışma Belleğine Etkisi}

Çalışma belleği, bilgilerin kısa süreli tutulduğu ve çoklu görevler gibi karmaşık görevlerin yapılabilmesinde rol oynayan bellek türüdür (Baddeley ve Hitch, 1974). Çalışma belleği birçok bileşenden oluşmakta olup, bu bileşenlerden birisi de merkezi yöneticidir. Baddeley ve Hitch'in (1974) modelinde yer alan merkezi yönetici, çalışma belleğinin karar verme mercii ve stratejilerin belirlenmesinden sorumludur. Ayrıca, görevlerin hangi sıra ile yapılacağına karar veren ve var olan dikkatin görevlere yönlendirilmesi ile görevlerin tamamlanmasını sağlayan bilişsel yapıdır (Baddeley, 2000). Merkezi yöneticiye destek olan fonolojik döngü depo ve iç tekrarlama (subvocal rehearsal) isimli iki yardımcı yapı sayesinde sözel bilgilerin tekrarlanabilip depolanabilmekte, görsel bilgiler ise görsel-mekânsal alan sayesinde kısa süreli depolanabilmektedir (Baddeley, 2000). Epizodik tampon ise yönetici merkez, fonolojik döngü, görsel-mekânsal alan ve uzun süreli bellek arasında köprü görevi gören bileşendir (Baddeley, 2000). 
Çalışma belleği doğru ilaç kullanımı gibi yaşamsal aktivitelerin yerine getirilebilmesinde önemli bir rol oynamaktadır (Insel, Morrow, Brewer ve Figueredo, 2006) ve ilerlemiş yaş ile pozitif korelasyon göstermektedir (Pliatsikas ve ark., 2019). Bu doğrultuda nasıl gelişebileceğinin araştırılması önemlidir. Bu çerçeve içerisinde, dijital oyunların çalışma belleğine olan etkisi geçmiş çalışmalar (Basak ve ark., 2008) tarafından araştırilmıştır.

Dijital oyun oynama sonrası ileri yetişkinlerde çalışma belleği performansında artış olduğu bulunmuştur. Basak ve arkadaşları (2008) planlama, strateji belirleme ve birçok görev arasında değişim gerektiren karmaşık oyunların belleği etkileyip etkilemediğini araştırmıştır. Yapılan deneylerin bulguları birbirine yaş, cinsiyet, eğitim ve zihinsel işlev olarak denk ileri yetişkinlerin 23,5 saat Rise of Nations (Big Huge Games, 2004) oynadıktan sonra kontrol grubuna kıyasla görsel kısa süreli belleklerinde iyileşme olduğunu göstermiştir. Kısa süreli bellek görevinde, katılımcılar farklı renklerde (kırmızı, yeşil, mavi, pembe ve siyah) ve yönlerde (dikey, yatay, sola veya sağa meyilli) gösterilen iki veya dört çizgiden oluşan bir ekranı gözlemlemiş ve kendilerinden ikinci gösterimde olan değişiklikleri söylemeleri istenmiştir. Deney bulguları özellikle dört çizgi olan denemelerde oyun oynayan bireylerin oyun oynamayan bireylere göre son-testte daha başarılı olduğunu göstermiştir (Basak ve ark., 2008). Bu bulgular, dijital oyun oynamanın çalışma belleğinin kapasitesini artırabileceğinin göstergesi olarak yorumlanabilir.

Çalışma belleği işlevlerden biri olan N-geri görevinde de dijital oyun oynamanın olumlu etkisinin olduğu görülmüştür (Basak ve ark., 2008). N-geri görevinde ekranda gösterilerin harflerin izlenmesi ve hedef harfin bir veya iki deneme önce gösterilen harfle aynı olup olmadığının önceden belirlenmiş tuşlara basarak belirtilmesi istenmektedir. Çalışma süresinde bireylerde oluşan bellek yükü bir ve iki geri denemeler arasındaki tepki süresi maliyetleri (reaction time costs) ile ölçülmüştür. 11 ile 23,5 saat arası süren oyun egzersizden sonra oyun oynama grubunun bellek yükü maliyetlerinin oyun oynamayan gruba göre azaldığı bulunmuştur (Basak ve ark., 2008). Bu bulgular, bellekte tutulabilen yükün dijital oyun oynama ile artabileceğine işaret etmektedir. Benzer bir şekilde, görsel desende eksik olan parçayı belirleme görevi içeren Raven'ın progresif matrislerindeki performansta 23,5 saat oyun oynama egzersizinden sonra artış olduğu bulunmuştur (Basak ve ark., 2008). Bu bulgular, dijital oyunların muhakeme becerilerini etkileyebileceğini göstermektedir. Ancak, Basak ve arkadaşlarının (2008) çalışmasında çalışma belleğini ölçmek için kullanılan işlem uzamı (operation span) görevinde 
dijital oyun oynamanın bir etkisinin olmadığı bulunmuştur. İşlem uzamı görevinde say1s1 üç ile altı arasında değişen birtakım kelimeler bellekte tutulmaya çalışıldığı sırada matematik problemlerinin çözülmesi istenmektedir (Basak ve ark., 2008). Sonrasında ise, sırası ile doğru hatırlanan kelime sayısı kayıt altına alınmaktadır.

\section{Dijital Oyunların İleri Yetişkinlerdeki Yönetici İşlevlere Etkisi}

Yönetici işlevler belirli bir amaca yönelik davranışların yerine getirilmesini sağlayıp, baskın olan davranışların engellenmesi, bilişsel esneklik (görev değiştirme) ve ça1ş̧ma belleğindeki bilgilerin güncellenmesi (Miyake ve ark., 2000) gibi işlemleri içerir. Yönetici işlevler ileri yetişkinlerin para sayabilme, telefon defterinden telefon numarası bulabilme gibi karmaşık görevleri yerine getirmelerinde önemli bir rol oynamaktadır (Nguyen, Copeland, Lowe, Heyanka ve Linck, 2020). Ancak bu işlevlerin performansı ileri yaşla beraber azalmaktadır (Harada, Natelson Love ve Triebel, 2013). Bu bağlam$\mathrm{da}$, bu becerilerin işlevlerinin artırılabilmesi için yöntemlerin araştırılması oldukça önemlidir.

Dijital oyunların merkezi yönetici işlevlerini olumlu etkilediği bulunmuştur. Basak ve ark. (2008) tarafından yapılan çalışmanın bir diğer bulgusu da dijital oyun oynayan bireylerin merkezi yönetici işlevlerinden olan görev değiştirme becerilerinde de iyileşme olduğudur. Görev değiştirme görevinde katılımcılar dönüşümlü olarak ya ekranda gösterilen rakamların tek veya çift sayı olup olmadığını belirtmeleri, ya da sayının beşten küçük veya büyük olup olmadığını söylemeleri istenmiştir. Hangi görevi tamamlamaları gerektiği ekrandaki arka plan rengine göre belirlenmekte olup ve bireyler önceden belirlenen tuşlara basarak yanıt vermektedir. Aynı görevin tekrarlandığ 1 ve tekrarlanmadığ 1 denemelerdeki tepki hızı farkı (değişim maliyeti, switch cost), görev değiştirme becerisindeki performansa göre değişmektedir. Denemeler ilerledikçe değişim maliyetinin oyun oynayan grupta, oynamayan gruba göre azaldığı bulunmuştur. Bu bulgular, oyun oynayan bireylerin bir göreve ait tepkilerin seçilmesini, bellekte güncel tutulmasını, sonrasında ise diğer görev setinin etkinleşmesini (Abutalebi ve Green, 2008; Monsell, 2003; Rubin ve Meiran, 2005) daha etkin bir biçimde yapılabildiğinin göstergesidir.

Basak ve arkadaşlarının (2008) çalışması dijital oyunların yönetici işlevleri olumlu etkileyebileceğini göstermiştir ancak yap-yapma görevinde dijital oyun oynamanın bir etkisinin olmadığı bulunmuştur. Yap-yapma görevinde ise katılımcılardan ekranda gösterilen $\mathrm{X}$ ve $\mathrm{O}$ harfler ile eşleşen tuşlara basarak tepki vermeleri, ancak belirli bir sesin 
duyulduğu denemelerde katılımcının tepki vermemesi istenmektedir. Böylelikle, beklenilen tepkilerin ketlenebilmesi ölçülmektedir. Bu görevlerdeki beceriler Rise of Nations (Big Huge Games, 2004) oyununda gerekli beceriler ile örtüşmemesi bir etkinin bulunmamasının olası bir sebebidir. Ancak aynı çalışmada uzak transfer etkisi görülmesi, bulguları karmaşık hale getirmektedir ${ }^{7}$. Bunun sebebi, oyun ile görev becerileri doğrudan örtüşmediği zamanlarda katılımcıların görsel-mekânsal belleğinde ve görev değiştirme becerilerinde dijital oyun oynama sonrası bir değişimin olmadığına dair bulgulardır (Ballesteros ve ark., 2014).

Dijital oyunlar ile yönetici işlevler arasındaki ilişkiyi araştıran bir diğer çalışma Nouchi ve arkadaşlarınınkidir (2012). Bu çalışmada ileri yetişkinler beş saat oyun oynamak üzere Brain Age (Nintendo, 2005) veya Tetris (Nintendo DS, 2006) grubuna atanıp deneyden önce ve sonra Frontal Değerlendirme Bataryası ${ }^{8}$ ve İz Sürme Testi-B ${ }^{9}$ ile kişilerin yönetici işlevleri ölçülmüştür. Brain Age (Nintendo, 2005), sesli okuma ve basit matematik problem çözme gibi prefrontal korteks işlemler içeren bir oyun olduğundan yönetici işlevler üzerinde pozitif bir etkiye neden olacağı düşünülmüştür. Tetris (Nintendo DS, 2006) ise zihinsel döndürme becerisi gerektirmekte olup; bireylerin ekranda yukarıdan aşağı inen blokları döndürerek yatay çizgi oluşturacak şekilde yerleştirmeleri gerektiğinden dolayı bireylerin yönetici işlevlerini etkilememesi beklenmekteydi. Çalışma sonucunda Brain Age (Nintendo, 2005) oyun grubunun Tetris (Nintendo DS, 2006) oyun grubuna göre son-testte her iki görevde de daha başarılı olduğu ve yönetici işlevlerinin olumlu etkilendiği, bilgi işleme hızının ise etkilenmediği bulunmuştur.

\section{Dijital Oyunların İleri Yetişkinlerdeki Sürdürülebilir, Seçici ve Bölünmüş Dikkate Etkisi}

Dikkat nesne, düşünce ve çevredeki uyaranlara odaklanabilme yetisidir. Sürdürülebilir dikkat odak noktamızı uzun süre koruyabilmemizi sağlarken, seçici dikkat birçok uyaranı göz ardı ederek istenilen uyarana odaklanabilmeyi sağlar. Öte yandan, bölünmüş dikkat birden fazla uyarana aynı anda odaklanabilmeyi sağlamaktadır. Özellikle bölünmüş dikkat düşmeden yürüyebilme (Melzer ve Oddsson, 2004; Verghese ve ark.,

\footnotetext{
7 Bahsi geçen kavram uzak transfer etkisi bölümünde açıklanmıştır.

8 Ölçme araçları: Benzerlikler (konseptualizasyon), kelime akıcılığı (mental esneklik), motor seriler, (programlama), çelişen yönergeler (interferansa duyarlılık), yap-yapma (inhibitör kontrol) ve yakalama davranışı (çevresel otonomi) (Tunçay, 2009).

9 İki görev rakamlar ve harfler arasında sırasıyla değişim yapılmasını gerektiriyor. Türkçe adaptasyonu Cangöz, Karakoç ve Selekler (2009) tarafindan gerçekleştirilmiştir.
} 
2002) gibi temel günlük yaşamsal aktivitelerin yerine getirilebilmesinde rol oynamaktadır. Bu beceriler ileri yaş ile kötüleştiğinden (McDowd ve Craik, 1988) bilişsel egzersizlerin odaklanabilme yeteneğini nasıl etkilediğinin araştırılması önemli hale gelmektedir.

Sürdürülebilir, Seçici ve Bölünmüş Dikkat ile Dijital Oyunlar. Dijital oyunların sürdürülebilir, seçici ve bölünmüş dikkatin üzerindeki etkisini araştıran çalışmaların bulguları çelişkiler içermektedir. Dijital oyunların yaşlı bireylerin bölünmüş dikkatlerine olan etkisini araştıran ilk çalışmalar (Huseyin ve Satyen, 2009) herhangi bir anlamlı bulgunun olmadığını göstermiştir. Bu çalışmalardan birini yapan Huseyin ve Satyen (2009), bölünmüş dikkatin ölçüm yollarından birisi olan bölünmüş dikkat paradigması$\mathrm{n} 1$ (Craik, Govoni, Naveh-Benjamin ve Anderson, 1996) uygulamıştır. Bu yöntemle bölünmüş dikkat, birincil bellek testi ve ikincil görev olan tepki zamanı görevinin eş zamanlı yapılması ile ölçülür. Her iki görevdeki performans, bölünmüş dikkatin göstergesidir. Huseyin ve Satyen (2009), üç saat dijital oyun oynama egzersizinden önce ve sonra bölünmüş dikkat becerilerini deney ve kontrol grupları için ölçmüştür. Deney sonuçları ise dijital oyun oynamanın bölünmüş dikkat becerisini etkilemediğini göstermiştir. Ayrıca, hatırlanan kelime sayısı artmamış ve tepki süreleri azalmamıştır. $\mathrm{Bu}$ çalışmada dijital oyunların kodlama ve geri çağırma becerilerini de etkilemediği bulunmuştur. Huseyin ve Satyen (2009) bölünmüş dikkat, tepki verebilme, kodlama ve geri çağırma gibi ileri yaştaki bireylerde kötüleşen işlevlerin iyileştirilebilmesi için egzersiz süresinin üç saatten fazla olması gerekebildiğini vurgulamıştır.

Benzer bir şekilde, Nouchi ve arkadaşlarının (2012) çalışmasında dikkat oranları ileri ve geri sayı menzili görevi gibi yöntemlerle ölçülmüş, söylenilen sayıların düz ve ters tekrarlanması istenmiştir. Bulgular dijital oyunların dikkat oranları üzerinde olumlu bir etkisinin olmadığını göstermektedir. Deney ve aktif kontrol gruplarının dikkat oranlarının eşit miktarda iyileşmesi, Nouchi ve arkadaşlarının (2012) çalışmasındaki istatistiksel olarak anlamlı olmayan bulguların olası sebeplerdendir.

Ancak bunların yanında dijital oyunlar ile dikkat arasında olumlu ilişki bulan çalışmalar da vardır. Örneğin, Mayas, Parmentier, Andres ve Ballesteros (2014) çalışmasında dikkat ve dikkat dağınıklığı oranları, sessiz ve sesli olmak üzeri iki farklı koşulda gerçekleşmiştir. Her iki koşulda da ekranda görülen bir ve sekiz rakamlarını tek veya çift sayı olup olmadığını tuşa basarak belirtmeleri istenmiştir. Katılımcılara sesli koşullarda sesi göz ardı ederek devam etmeler söylenmiştir. Bu çalışmanın bulguları Lumosity (Sarkar 
ve ark., 2007) oyununu oynama sonucu katılımcıların dikkatlerinde artış ve dikkat dağ1nıklığında azalma göstermiştir. Diğer bir değişle gereksiz uyaranları göz ardı ederek hedef göreve odaklanabilme becerisinin dijital oyunlar sayesinde geliştiği bulunmuştur.

Anguera ve arkadaşlarının (2013) çalışmasında çoklu görev becerileri gerektiren Neuroracer (Gazzaley, 2013) oyununu oynayan grubun aktif ve pasif kontrol grubuna göre çoklu görev performansının daha iyi olduğu gözlemlenmiştir. Ayrıca bu oyunun oynamanın bilişsel yaşlanmadan etkilenen sürdürebilir dikkati ve çalışma belleğini de geliştirdiği, ancak bölünmüş dikkati etkilemediği bulunmuştur. Diğer bir çalışmada, 540 saat egzersiz sonrası Useful Field of View Performance (UFOV) grubu, hedef aksiyon oyun grubu (Medal of Honour-Rising Sun) (EA Los Angeles, 2003) ve plasebo kontrol arcade oyun gruplarının (Tetris Worlds) (Blue Planet Software, 2001), pasif kontrol grubuna göre UFOV testindeki seçici dikkat görevinde daha başarılı olduğu bulgusuna ulaŞılmıştır (Belchior ve ark., 2013). Diğer bir deyişle, egzersiz yapan bireylerin gereksiz uyaranları göz ardı ederek ekranın merkezinde duran nesneyi adlandırma ve ekranın çevresinde olan nesnenin yerinin tespit edebilme işlevinin arttı̆̆ı söylenebilir. Seçici dikkatin dijital oyun oynama gruplarına göre en fazla UFOV grubunda artmas ${ }^{10}$, egzersiz ile görev arasındaki becerilerin örtüşmesinin önemine işaret etmektedir.

Yapılan çalışmalar, ileri yetişkinlerde bölünmüş dikkat becerilerinin gelişmesinde değişen öncelik egzersizlerinin (variable priority training) etkili olduğu gösterilmiştir (Kramer, Larish ve Strayer, 1995). Bu doğrultuda, Zhang, Grenhart, Sphufera, McLaughlin ve Allaire (2019), bu yöntemin dijital oyun ile egzersiz yapılması sonucu seçici ve bölünmüş dikkat oranlarını (ve diğer bilişsel işlevleri ${ }^{11}$ ) etkileyip etkilemediğini araştırmışlardır. Değiş̧en öncelik egzersizi yöntemi, bireylerin bir oyunun alt görevlerini teker teker (tek öncelik egzersizler - single priority training) veya tüm alt görevlerini aynı anda (değişen öncelik egzersizler) oynamasını içermektedir. Değişen öncelik egzersizi koşulunda katılımcılardan dikkatlerini odaklarken alt görevlerin sadece bir tanesine öncelik verip bu hedef görevdeki başarılarının \%80, diğer görevlerde ise başarı oranlarının \%20 olması istenmiştir. Seçici ve bölünmüş dikkat UFOV testi ile ölçülmüştür. Çalışmanın bulguları, değişen öncelik egzersizi sonrası seçici dikkat, bölünmüş dikkat ve bilgi işlem hızında herhangi bir gelişme olmadığını göstermiştir. Bir diğer değişle,

10 Not edilmelidir ki gruplar arasındaki fark anlamlı düzeyde değil.

11 Dijital oyunların zihinsel işlev, akıl yürütme, bellek, yönetici işlevler ve çalışma belleği üzerinde hiçbir etkisinin olmadığı bulunmuştur. 
odaklanmanın birden fazla göreve dikkatin verilebilmesini olumlu etkilemediği bulunmuştur. Tek öncelik egzersizler grubunun kontrol grubu olması, bu gruptaki bireylerin de seçici dikkatlerinin artmış olması, gruplar arasında herhangi bir fark bulunmamas1nın sebebi olabilir (Zhang ve ark., 2019). Mevcut çelişkili bulgular karşısında, dijital oyunların bölünmüş dikkatin üzerindeki etkisi net değildir. Konuyla ilgili daha fazla araştırma yapılması gerekmektedir.

\section{Dijital Oyunların İleri Yetişkinlerdeki Uzak Transfere Etkisi}

Dijital oyunların gerektirdiği beceriler ile bilişsel görevlerin örtüşmesi beklenilen bir bulgudur. Ancak oyunlar ile doğrudan bağlantılı olmayan becerilerin de iyileşmesi, diğer bir deyişle uzak transfer etkisi, oyunların daha fazla bilişsel süreç iyileştirebilme potansiyelinin olduğunu göstermektedir. Örneğin, Basak ve arkadaşları (2008) ileri yetişkinlerin strateji içeren oyun ile egzersiz yaptıktan sonra zihinsel döndürme becerilerinin (iki ve üç boyutlu nesnelerin zihinsel döndürülerek nasıl görüneceğinin belirlenmesi) artı̆̆ı bulunmuştur. Bu bulgu bir uzak transfer etkisinin örneğidir; oyun içerisinde zihinsel olarak nesnelerin döndürülmesi gerekmemektedir. Fakat transfer etkisi gösteren bulgular birbirleriyle çelişmektedir. Transfer etkisi bulan (Belchior ve ark., 2013), bulmayan (Ballesteros ve ark., 2014; Goldstein ve ark., 1997) ve kendi içerisinde farkl1lıklar gösteren (Anguera ve ark., 2013; Basak ve ark., 2008) çalışmalar bulunmaktadır. Örneğin çoklu görev becerileri gerektiren oyunlar (Neuroracer) (Gazzaley, 2013) sürdürebilir dikkati ve çalışma belleğini etkilerken, bölünmüş dikkat ve hızlı bilgi işleme yapmayı gerektiren görevlerde bir etkilerinin olmadığı bulunmuştur (Anguera ve ark., 2013).

Farklı bulgulara ulaşılmasında etkili olma ihtimali olan oyun türü, oynama süresi ve oyun becerisi gibi değişkenlerin yanı sıra bilişsel işlevlerin ölçülme yöntemlerinin de birbiriyle çelişkili sonuçlar üzerinde bir etkisi olup olmadığı araştırılmıştır. Basak ve arkadaşlarının (2008) çalışmasında merkezi yönetici beceriler gerektiren bir oyunun dört görsel-mekânsal dikkat görevinden sadece birini; zihinsel döndürme görevini etkilediği bulunmuştur. Zihinsel döndürme görevi hız ve doğruluk gerektirirken, diğer üçünün (Functional Field of View, Attentional Blink ve Enumeration) sonuç ölçüsü sadece doğruluk olarak karşımıza çıkmaktadır. Ayrıca oyun oynamanın işlem hızını etkilediği (Dye, Green ve Bavelier, 2009) ve genç oyuncularda oyun sonrası dikkat kontrolü ile ilgili beyin bölgelerinin; sağ orta frontal girus, sağ üst frontal girus ve ventral medial prefrontal korteksin daha az aktif olduğu da bulunmuştur (Prakash ve ark., 2012). Prakash ve arkadaşları (2012), dikkat kontrolü ve çoklu görev becerileri gerektiren beyin 
bölgelerinin daha az aktif olmasının sebebinin oyun pratiği sayesinde otomatik işleme geçiş yapılması ve bu bölgelere daha az ihtiyaç duyulması olduğu sonucuna ulaşmışlardır. Prakash ve arkadaşlarına (2012) göre bireyler bu sayede bilişsel kaynaklarını görevlere daha iyi dağıtılabilmektedirler.

Bu bulgular 1şı̆̆ında merkezi yönetici işlevlerin ve hız gerektiren oyunların bilişsel kaynakların görevlere daha iyi dağıtılabilmesini ve hız gerektiren görevlerdeki başarıyı arttırıp arttırmadığ karşın diğer çalışmalarda (örn., Anguera ve ark., 2013), hızlı bilgi işleme yapmayı gerektiren görevlerde transfer etkisinin olmaması, bulguların yorumlanmasını güçleştirmektedir. Bu nedenle, transfer etkisinin hangi koşullarda gerçekleştiğinin araştırılması önemlidir.

\section{Bilişsel Süreçlerin Korunması}

Bilişsel egzersizler (kitap okuma gibi) sayesinde normal yaşlanmadan dolayı azalan bilişsel işlevlerin sabit düzeyde tutulması veya iyileşmesi 'kullan veya kaybet' (use it or lose it) hipotezi ile uyumludur ve beynin işlevini koruyabildiğinin göstergesidir (Cangöz, 2008). $\mathrm{Bu}$ iyileşen becerilerin uzun süre sürdürülebilmeleri mümkün müdür? Bazı araştırmalar, merkezi yönetici işlevleri ve tepki hızındaki iyileşmelerin bir süre sonra muhafaza edilmediğini bulurken (Ballesteros ve ark., 2015; Stern ve ark., 2011); başka araştırmalar çoklu görev becerilerinin altı aya kadar korunduğunu bulmuştur (Anguera ve ark., 2013). Fakat aynı çalışma içerisinde (Toril, Reales, Mayas ve Ballesteros, 2016) farklı bulgular mevcuttur; örneğin görsel-mekânsal çalışma belleği yapboz-bulmaca (jigsaw-puzzle) görevi ile ölçüldüğü zaman becerinin üç ay sonra korunduğu, ancak Corsi blok görevi ile ölçüldüğünde korunmadığı bulunmuştur. İyileşen becerilerin hangi koşullar altında korunduğu net değildir, bu nedenle bu konuda daha fazla araştırmaya ihtiyaç duyulmaktadır.

\section{TARTIŞMA}

Genel olarak, farklı türlerde ve sürelerde dijital oyun oynamanın ileri yetişkinlerin bilişsel becerilerini iyileştirdiği söylenebilir (Basak ve ark., 2008; Clark ve ark., 1987; Dustman ve ark., 1992). Özellikle tepki süresi (Clark ve ark., 1987; Dustman ve ark., 1992), çalışma belleğinin (Basak ve ark., 2008), yönetici işlevlerinin (Basak ve ark., 2008; Nouchi ve ark., 2012) ve sürdürebilir ve seçici dikkat becerilerinin (Anguera ve ark., 2013; Belchior ve ark., 2013) dijital oyunlarla artırllabileceği gösterilmiştir. Bu bulgular bilişsel egzersiz bakış açısı ile uyumlu olup, tekrar eden pratik becerilerin gelişmesinden kaynak- 
lanmaktadır. Ayrıca, genellikle hız, odaklanma ve esneklik gerektiren oyunların bilişsel becerilerin gelişmesinde rol oynadığı görülmüştür (Ballesteros ve ark., 2014; Clark ve ark., 1987). Ancak gelişen bilişsel beceriler dijital oyundan mı kaynaklıdır, yoksa herhangi bir aktivite de aynı iyileşmeye neden olabilir mi sorusu halen belirsizliğini korumaktadır. Bazı araştırmalarda aktif kontrol gruplarının (Belchior ve ark., 2013, van Muijden, Band ve Hommel, 2012) seçici dikkat becerilerini iyileştirmesi, herhangi bir zihinsel simülasyonun da bilişsel süreçleri iyileştirebileceği düşüncesini akla getirmektedir. Bu nedenle konuyla ilgili daha fazla araştırmaya ihtiyaç vardır. Bunun yanında ileri yetişkinlerde bilişsel süreçlerin iyileşmesinde dijital oyunlar ile beyin plastisitesi arasındaki iliş̧inin önemini vurgulayabilmek için katılımcılardan davranışsal ölçümlerin yanı sıra oyun oynama sonrası beyin bölgesi aktivasyonu ile beyin hacmi ölçümlerinin de alınması gereklidir. $\mathrm{Bu}$ doğrultuda alan yazında daha fazla çalışmaya ihtiyaç vardır.

Bölünmüş dikkatin dijital oyunlardan etkilenmemesinin oyun oynama süresinin yetersiz olması gibi deneysel sınırlılıklardan kaynaklı olması olasıdır. Ancak birçok araştırmada farklı koşullar, oyunlar ve yöntemler kullanılmasına rağmen olumlu bir etkinin bulunmaması, dijital oyunların bölünmüş dikkati geliştirme yeterliliğine sahip olmad1ğını düşündürmektedir. Yine de bu konuyla ilgili kesin yargılara varmadan önce bilişsel gerileme oranı, oyun oynama motivasyonu gibi karıştırıcı etki oluşturabilecek ara değişkenlerin araştırılması gerekmektedir. Örneğin bilişsel gerileme oranının, oyun oynamadan elde edilebilecek kazanç üzerinde aracı bir etkiye sahip olması mümkün müdür? Whitlock, McLaughlin ve Allaire (2012) dikkat kontrol becerileri daha az olan ileri yetişkinlerin oyun oynamadan en fazla fayda sağladığını bulmuştur. Öte yandan, Toril ve arkadaşlarının (2016) çalışmasında, katılımcıların tanıma becerileri iyileşirken serbest çağrışımlarının iyileşmediği bulunmuştur. Bu örnekler, kişisel farklılıkların oyun oynamadan oluşabilecek bilişsel kazanca ne kadar ve hangi koşullarda aracılık ettiğinin daha fazla araştırılması gerektiğini göstermektedir.

\section{Gelecek Deneyler: Yöntemsel İyileşme ve Ekolojik Geçerlilik}

İleri yetişkinlerde iyileşen becerilerin uygulamalardan ziyade plasebo etkisinden kaynaklı olmadığına dair de herhangi bir somut bulgu bulunmamaktadır. Bazı çalışmalarda (Anguera ve ark., 2013; Belchior ve ark., 2013; Dustman ve ark., 1992; Mayas ve ark., 2014; Nouchi ve ark., 2012; van Muijden ve ark., 2012) aktif kontrol gruplarının olması plasebo etkilerin ortadan kaldırılması için yeterli gelmemiştir. Bunun sebebi, medya ve halk arasında 'sudoku/bulmaca gibi oyunların' demanstan koruyabileceği bil- 
gisinin olması, katılımcıların hangi gruplara atandıklarının farkında olmaları, oyun ile görev arasındaki bağlantıyı fark edip başarmak için motivasyonlarının ve dolayısıyla görev performanslarının artması olabilir (Boot, Blakely ve Simons, 2011; Boot, Simons, Stothart ve Stutts, 2013). Bir araştırma, genç bireylerde oyun oynama arzusu ile hipokampus ve DLPFC beyin bölgelerindeki gri madde hacimlerinin ilişkili olduğunu göstererek bahsedilen karıştırıcı değişkenlerin olası etkisine parmak basmıştır (Kühn, Gleich, Lorenz, Lindenberger ve Galliant, 2014). Bu duruma çözüm getirmek için Boot ve arkadaşları $(2011$; 2013) deneysel, aktif ve pasif kontrol gruplarının yanı sıra, deney sonrasında katılımcıların oyun oynama ile biliş arasındaki ilişkiyi bilip bilmediklerini ölçülmesi gerektiğini vurguluyor. Ayrıca, oyun oynama, bilişsel görevi tamamlama veya deneye katılma motivasyonlarını ölçüp bu değişkenlerin gruplar arasında eşit olması gerektiğini vurguluyor. İleri yaştaki bireyler ile ilgili çalışmalarda bunu henüz etkili bir biçimde yapan araştırma yoktur.

Oyun oynamanın bilişsel becerileri nasıl iyileştirdiği net değildir. Dolayısıyla sadece pratik yapılan becerileri mi iyileştirdiği, yoksa artan beynin plastisitesinden kaynaklı diğer işlevleri de mi iyileştirdiği, açıklama bekleyen sorular arasındadır. Dahası oyun oynamanın etkilerinin (eğer var ise) uzun ömürlü olup olmadığı ve bunu etkileyen faktörlerin belirlenmesi gerekmektedir. İyileşen bilişsel beceriler gerçek hayattaki günlük yaşamsal aktivitelere aktarılmadığı sürece sadece laboratuvar ortamında iyileştiklerini tespit etmek de pek yararlı değildir. Sonuçta bilişsel egzersizlerin bilişsel işlevleri iyileştirip nihayetinde kişilerin yaşamsal kalitelerini artırması hedeflenmektedir. Dijital oyunlar, tepki süresini ve merkezi yönetici işlevleri geliştiriyor ise, bu becerileri gerektiren günlük yaşamsal aktiviteleri örneğin güvenli araba kullanmayı da iyileştirmesi beklenmektedir. Yapılan alan yazın taramasında böyle bir etkiyi, diğer bir deyişle ekolojik geçerliliği gösteren bir araştırmaya rastlanmamıştır. Dijital oyunlar sayesinde bilişsel yaşlanmadan ve getirdiği olumsuz etkilerden, örneğin düşme ve düşmeden kaynaklı yaralanmalardan (Liu, Chan ve Yan, 2014; Muir, Gopaul ve Odasso, 2012) korunup korunmadığımızı belirlemek için bu alanda daha fazla çalışmaya ihtiyaç vardır.

Dijital egzersizlerin biliş üzerindeki etkilerinin araştırılması, normal yaşlanmadan kaynaklı azalan bilişsel işlevlerin korunması veya geliştirilmesi açısından oldukça önemlidir. Bir diğer önemi ise, bu uygulamaların Hafif Bilişsel Bozukluk (HBB) ${ }^{12}$ ve

12 Demans tanısı alacak kadar ilerlememiş, normal bilişsel yaşlanmadan farklı seyreden bilişsel işlev kaybı olarak tanımlanmaktadır (Cangöz, 2017). 
Alzheimer Tipi Demans (ATD) gibi patolojik boyutta olan biliş kayıplarını önleyebilme yetisinin olup olmadığıdır. Bu bağlamda, Cangöz, Çağıltay, Özel Kızıl, Oktay ve Özcan (2017) (akt., Cangöz, 2018), normal bilişsel yaşlanma sürecinde olan ATD ve HBB'li hastalar için bilgisayar destekli oyun egzersiz programı geliştirmiş̧ir. ATD ve HBB'li yaşlı bireyler haftada üç gün ve bu günlerde bir saat; toplamda 88 saat olmak üzere bilgisayar destekli oyunlar ile egzersiz yapmışlardır. Ön sonuçlar, egzersiz sonrası nöropsikolojik test puanlarının sabit kaldığını göstermiştir. Uzun vadede bilgisayar destekli oyunların patolojinin ilerlemesini nasıl etkileyeceğinin araştırılması, bilişsel rehabilitasyon yönünden önem kazanacaktır.

\section{SONUÇ VE ÖNERILLER}

Dijital oyun oynamanın normal yaşlanmadan dolayı azalan bilişsel becerileri iyileştirip iyileştirmediği güncel bir araştırma konusudur. Oyunların kolaylıkla erişilebilir ve eğlenceli olması bilişsel kazanç elde edebilmek için gerekli miktardaki pratik sağlamaları onları çekici bilişsel egzersiz yöntemi yapmaktadır. Ancak oyunların bilişsel avantajlarından net olarak bahsedebilmek için motivasyon etkeninin ortadan kaldırılması ve bu bilişsel etkilerin laboratuvar dışına, gerçek yaşamsal aktivitelere transfer edilmesi gerekmektedir. Dijital oyunlar ile ileri yetişkinlerin tepki süreleri arasındaki bağlantıyı daha kapsamlı anlayabilmek için dijital oyunların uyaran algılama gibi diğer bilgi işleme süreçlerini de etkileyip etkilemediği araştırılmalıdır. Ayrıca, gelecek çalışmalar, basit, iki, dört, altı ve sekiz seçmeli tepki zamanı görevlerini kıyaslayarak dijital oyunların etkisinin görevlerin tamamlanabilmesi için gerekli olan beceriler ile ilişkili olup olmadığının incelenmesi önerilir. Dijital oyun oynamanın patolojik boyutta olan biliş kayıplarını önleyebilme yetisinin olup olmadığı daha fazla araştırma gerektirmektedir.

Teşekkür: Araştırma metninin düzenlenmesi konusunda yardımları için Uzm. Sosyal Psk. Elif Öykü Us'e teşekkür ederim.

Hakem Değerlendirmesi: Dış bağımsız.

Çıkar Çatışması: Yazar çıkar çatışması bildirmemiştir.

Finansal Destek: Yazar bu çalışma için finansal destek almadığını beyan etmiştir.

Peer-review: Externally peer-reviewed.

Conflict of Interest: The author has no conflict of interest to declare.

Grant Support: The author declared that this study has received no financial support. 


\section{Kaynakça/References}

Abutalebi, J. ve Green, D. W. (2008). Control mechanisms in bilingual language production: Neural evidence from language switching studies. Language and Cognitive Processes, 23(4), 557-582. https://doi.org/10.1080/01690960801920602

Activision. (1983). Kaboom! [video oyunu]. Santa Monica: Activision.

American Association of Retired Persons. (2019). Gaming attitudes and habits of adults ages 50-plus. https://doi.org/10.26419/res.00328.001

Anderson, C. A. ve Bushman, B. J. (2001). Effects of violent video games on aggressive behaviour, aggressive cognition, aggressive affect, physiological arousal, and prosocial behaviour: A metaanalytic review of the scientific literature. Psychological Science, 12(5), 353- 359.

Anguera, J. A., Boccanfuso, J., Rintoul, J. L., Al-Hashimi, O., Faraji, F., Janowich, J., Kong, E., Larraburo, Y., Rolle, C., Johnston, E. ve Gazzaley, A. (2013). Video game training enhances cognitive control in older adults. Nature, 501(7465), 97-101. https://doi.org/10.1038/nature12486

Atari, Inc. (1976). Breakout [Arcade oyunu]. Sunnyvale: Atari, Inc.

Baddeley, A. D. (2000). The episodic buffer: A new component of working memory? Trends in Cognitive Science, 4, 417-423.

Baddeley, A. ve Hitch, G. (1974). Working memory. G. A. Bower (Ed.), The psychology of learning and motivation içinde (ss. 47-89). New York: Academic Press.

Balkan, E. ve Adalier, A. (2011). The relationship between social cohesion and computer-internet usage. The Turkish Online Journal of Educational Technology, 102(3), 304-310.

Ballesteros, S., Prieto, A., Mayas, J., Toril, P., Pita, C., de León, L. P., Reales, J. M. ve Waterworth, J. (2014). Brain training with non-action video games enhances aspects of cognition in older adults: A randomized controlled trial. Frontiers in Aging Neuroscience, 6(277). https://doi.org/10.3389/ fnagi.2014.00277

Ballesteros, S., Mayas, J., Prieto, A., Toril, P., Pita, C., Ponce de León, L., Reales, J. M. ve Waterworth, J. A. (2015). A randomized controlled trial of brain training with non-action video games in older adults: Results of the 3-month follow-up. Frontiers in Aging Neuroscience, 7(45). https://doi. org/10.3389/fnagi.2015.00045

Baran, A. G., Kurt, S. K. ve Tekeli. E. S. (2017). Yaşlıların dijital teknolojileri kullanım düzeyleri üzerine bir araştırma. Illetişim Kuram ve Araştırma Dergisi, 45, 1-24.

Basak, C., Boot, W. R., Voss, M. W. ve Kramer, A. F. (2008). Can training in a real-time strategy video game attenuate cognitive decline in older adults? Psychology and Aging, 23(4), 765-777. https:// doi.org/10.1037/a0013494

Bavelier, D., Levi, D. M., Li, R. W., Dan, Y. ve Hensch, T. K. (2010). Removing brakes on adult brain plasticity: From molecular to behavioral interventions. The Journal of Neuroscience, 30(45), 14964-14971. https://doi.org/10.1523/JNEUROSCI.4812-10.2010

Bayraktar, F. ve Gün, Z. (2007). Incidence and correlates of Internet usage among adolescents in North Cyprus. CyberPsychology \& Behavior, 10(2), 191-197. https://doi.org/10.1089/cpb.2006.9969

Becerikli, Y. S. (2013). Kuşaklararası iletişim açısından yeni iletişim teknolojilerinin kullanımı: İleri yaş grubu üzerine bir değerlendirme. Ístanbul Üniversitesi İletişim Fakültesi Dergisi, 1(44), 19-31. https://dergipark.org.tr/tr/pub/iuifd/issue/22894/245013

Belchior, P., Marsiske, M., Sisco, S. M., Yam, A., Bavelier, D., Ball, K. ve Mann, W. C. (2013). Video game training to improve selective visual attention in older adults. Computers in Human Behavior, 29(4), 1318-1324. https://doi.org/10.1016/j.chb.2013.01.034 
Bell-McGinty, S., Podell, K., Franzen, M., Baird, A. D. ve Williams, M. J. (2002). Standard measures of executive function in predicting instrumental activities of daily living in older adults. International Journal of Geriatric Psychiatry, 17(9), 828-834. https://doi.org/10.1002/gps.646

Big Huge Games (2004). Rise of Nations [Bilgisayar video oyunu]. Redmond: Microsoft Game Studios Blue Planet Software (2001). Tetris Worlds [video oyunu]. Agoura Hills: THQ

Boot, W. R., Blakely, D. P. ve Simons, D. J. (2011). Do action video games improve perception and cognition? Frontiers in Psychology, 2(226), 1-6. PMCID: PMC3171788

Boot, W. R., Simons, D. J., Stothart, C. ve Stutts, C. (2013). The pervasive problem with placebos in psychology: Why active control groups are not sufficient to rule out placebo effects. Perspectives on Psychological Science, 8(4), 445-454. https://doi.org/10.1177/1745691613491271

Botwinick, J. ve Thompson, L. W. (1966). Premotor and motor components of reaction time. Journal of Experimental Psychology, 71(1), 9-15. https://doi.org/10.1037/h0022634.

Cahn-Weiner, D. A., Boyle, P. A. ve Malloy, P. F. (2002). Tests of executive function predict instrumental activities of daily living in community-dwelling older individuals. Applied Neuropsychology, 9(3), 187-191. https://doi.org/10.1207/S15324826AN0903_8

Cai, L., Chan, J. S. Y., Yan, J. H. ve Peng, K. (2014). Brain plasticity and motor practice in cognitive aging. Frontiers in Aging Neuroscience, 6, 31. https://doi.org/10.3389/fnagi.2014.00031

Cangöz, B. (2008). Yaşlılık: Sadece kayıp mı? Bir ayrıcalık mı? Türk Geriatri Dergisi, 11(3), 143-150.

Cangöz, B. (2017). Evaluation of cognitive processes. M. Farmosa ve Y. G. Kutsal (Ed.) içinde, Population aging in Turkey: Social and health care services for older persons (ss.99-108). International Institute of Aging (INIA) Publication. United Nations - Malta: Progress Press.

Cangöz, B. (2018). Yaşlilarda bilişsel rehabilitasyon. E. Özmete ve G. Baştuğ (Ed.), Yaşlılarda psikolojik ve sosyal rehabilitasyon içinde (ss. 22-29). Ankara: Hedef Yayıncılık.

Cangöz, B., Karakoç, E. ve Selekler, K. (2009). Trail Making Test: Normative data for Turkish elderly's by age, sex and education. Journal of the Neurological Sciences, 283(1-2), 73-78.

Cepeda, N.J., Blackwell, K.A. ve Munakata, Y. (2013). Speed isn’t everything: Complex processing speed measures mask individual differences and developmental changes in executive control. Developmental Science, 16(2), 269-286. https://doi.org/10.1111/desc.12024

Coreland (1982). Pengo [arcade oyunu]. Shinagawa: Sega.

Clark, J. E., Lanphear, A. K. ve Riddick, C. C. (1987). The effects of videogame playing on the response selection processing of elderly adults. Journal of Gerontology, 42(1), 82-85. https://doi. org/10.1093/geronj/42.1.82

Craik, F. I. M., Govoni, R., Naveh- Benjamin, M. ve Anderson, N. D. (1996). The effect of divided attention on encoding and retrieval processes in human memory. Journal of Experimental Psychology: General, 125(2), 159- 180.

Dearly, I. J., Liewald, D. ve Nissan, J. (2011). A free, easy-to-use, computer-based simple and fourchoice reaction time programme: The Deary-Liewald reaction time task. Behavior Research Methods, 43(1), 258-68. https://doi.org/10.3758/s13428-010-0024-1

DeFelipe, J. (2006). Brain plasticity and mental processes: Cajal again. Nature Reviews Neuroscience, 7(10), 811-817. https://doi.org/10.1038/nrn2005

Dustman, R. E., Emmerson, R. Y., Steinhaus, L. A., Shearer, D. E. ve Dustman, T. J. (1992). The effects of videogame playing on neuropsychological performance of elderly individuals. Journal of Gerontology, 47(3), P168-P171. https://doi.org/10.1093/geronj/47.3.P168

Dye, M. W., Green, C. S. ve Bavelier, D. (2009). Increasing speed of processing with action video games. Current Directions in Psychological Science, 18(6), 321-326. https://doi.org/10.1111/ j.1467-8721.2009.01660.x 
EA Los Angeles. (2003). Medal of Honor-Rising Sun [birinci şahıs nişancı oyunlarını]. Redwood City: Electronic Arts.

Fletcher, B. ve Rabbitt, P. M. A. (1978). The changing pattern of perceptual analytic strategies and response selection with practice in a two-choice reaction time task. Quarterly Journal of Experimental Psychology, 30, 417-427. https://doi.org/10.1080/00335557843000025

Gazzaley, A. (2013). NeuroRacer [arcade oyunu]. San Francisco: University of California General Computer Corporation. (1982). Ms. PacMan [arcade oyunu]. Chicago: Midway Games.

Goldstein, J. H., Cajko, L., Oosterbroek, M., Michielsen, M., Van Houten, O. ve Salverda, F. (1997). Video games and the elderly. Social Behavior and Personality: An International Journal, 25, 345352. https://doi.org/10.2224/sbp.1997.25.4.345

Gökkaya, Z. ve Deniz, L. (2014). Üniversite öğrencilerinin bilgisayar oyunun oynama alışkanlıkları ve oyun tercihleri: Marmara Üniversitesi örneği. Akademik Sosyal Araştırmalar Dergisi, 2(6), 58-73.

Güvenli İnternet Merkezi. (2019). Dijital oyunlar raporu. https://www.guvenliweb.org.tr/dosya/RjARy. pdf

Harada, C. N., Natelson Love, M. C. ve Triebel, K. L. (2013). Normal cognitive aging. Clinics in Geriatric Medicine, 29(4), 737-752. https://doi.org/10.1016/j.cger.2013.07.002

Held, R. (1965). Plasticity in sensory-motor systems. Scientific American, 213(5), 84-94. https://doi. org/10.1038/scientificamerican1165-84

Hilchey, M. D. ve Klein, R. M. (2011). Are there bilingual advantages on non-linguistic interference tasks? Implications for the plasticity of executive control processes. Psychological Bulletin Review, 18, 625-658. https://doi.org/10.3758/s13423-011-0116-7

Huseyin, I. ve Satyen, L. (2009). Training divided attention and memory skills of older adults. (Doktora tezi). Deakin University, Geelong.

Insel, K., Morrow, D., Brewer, B. ve Figueredo, A. (2006). Executive function, working memory, and medication adherence among older adults. The Journals of Gerontology Series B: Psychological Sciences and Social Sciences, 61(2), P102-P107. https://doi.org/10.1093/geronb/61.2.P102

Jones, C. M., Scholes, L., Johnson, D., Katsikitis, M. ve Carras, M. C. (2014). Gaming well: Links between videogames and flourishing mental health. Frontiers in Psychology, 5(260). https://doi. org/10.3389/fpsyg.2014.00260

Kahlbaugh, P. E., Sperandio, A. J., Ashley L. Carlson, A. L. ve Hauselt, J. (2011). Effects of playing Wii on well-being in the elderly: Physical activity, loneliness, and mood. Activities, Adaptation \& Aging, 35(4), 331-344. https://doi.org/10.1080/01924788.2011.625218

Karakuş, T., Inan, Y. ve Çağıltay, K. (2008). A descriptive study of Turkish high school students. Computers in Human Behavior, 25(6), 2520-2529. https://doi.org/10.1016/j.chb.2008.03.011

Kaşıkçı, D. N., Çağıltay, K., Karakuş, T., Kurşun, E. ve Ogan, C. (2014). Türkiye ve Avrupa'daki çocukların internet alışkanlıkları ve güvenli internet kullanımı. Ĕ̈itim ve Bilim, 39(171), 230-243.

Kirby, A., Jones, C. ve Copello, A. (2014). The impact of massively multiplayer online role playing games (MMORPGS) on psychological wellbeing and the role of play motivations and problematic use. International Journal of Mental Health Addiction, 12, 36-51. https://doi.org/10.1007/s11469013-9467-9

Konami. (1981). Frogger [Arcade oyunu]. Shinagawa: Sega.

Kramer, A. F., Larish, J. F. ve Strayer, D. L. (1995). Training for attentional control in dual task settings: A comparison of young and old adults. Journal of Experimental Psychology: Applied, 1(1), 5076. https://doi.org/10.1037/1076-898X.1.1.50 
Kühn, S., Gleich, T., Lorenz, R. C., Lindenberger, U. ve Galliant, J. (2014). Playing Super Mario induces structural brain plasticity: Gray matter changes resulting from training with a commercial video game. Molecular Psychiatry, 19, 265-271. https://doi.org/10.1038/mp.2013.120

Lajoie, Y. ve Gallagher, S. P. (2004). Predicting falls within the elderly community: Comparison of postural sway, reaction time, the Berg balance scale and the Activities-specific Balance Confidence $(\mathrm{ABC})$ scale for comparing fallers and non-fallers. Archives of Gerontology and Geriatrics, 38, $11-26$

Liu, Y., Chan, J. S. Y. ve Yan, J. H. (2014). Neuropsychological mechanisms of falls in older adults. Frontiers in Aging Neuroscience, 6(64). https://doi.org/10.3389/fnagi.2014.00064

Mayas, J., Parmentier, F. B. R., Andres, P. ve Ballesteros, S. (2014). Plasticity of attentional functions in older adults after non-action video game training: A randomized controlled trial. PLoS ONE 9(3): e92269. https://doi.org/10.1371/journal.pone.0092269

McDowd, J. M. ve Craik, F. I. (1988). Effects of aging and task difficulty on divided attention performance. Journal of Experimental Psychology: Human Perception and Performance, 14(2), 267-280.

Melzer, I. ve Oddsson, L. I. E. (2004). The effect of a cognitive task on voluntary step execution in healthy elderly and young individuals. Journal of the American Geriatrics Society, 52(8), 12551262.

Mind's Eye Production. (2000). Pac-Man: Adventure in Time. [video oyunu]. Alameda: Hasbro Interactive.

Miyake, A., Friedman, N. P., Emerson, M. J., Witzki, A. H., Howerter, A. ve Wager, T. D. (2000). The unity and diversity of executive functions and their contributions to complex "Frontal Lobe" tasks: A latent variable analysis. Cognitive Psychology, 41(1), 49-100. https://doi.org/10.1006/ cogp.1999.0734

Monsell, S. (2003). Task switching. Trends in Cognitive Science, 7(3), 134-140. https://doi.org/10.1016/ S1364-6613(03)00028-7

Mowbray, G. H. (1960). Choice reaction times for skilled responses. Quarterly Journal of Experimental Psychology, 12, 193-202. https://doi.org/10.1080/17470216008416726.

Mowbray, G.H.veRhoades, M.V.(1959). Onthereduction of choicereaction times with practice. Quarterly Journal of Experimental Psychology, 11(1), 16-23. https://doi.org/10.1080/17470215908416282

Muir, S. W., Gopaul, K. ve Odasso, M. M. M. (2012). The role of cognitive impairment in fall risk among older adults: A systematic review and meta-analysis, Age and Ageing, 41(3), 299-308. https://doi. org/10.1093/ageing/afs012

Myerson, J. S., Robertson, S. ve Hale, S. (2007). Aging and intra-individual variability in performance: Analysis of response time distributions. Journal of the Experimental Analysis of Behavior, 88(3), 319-337.

Namco. (1980a). Galaxian [birinci şahıs nişancı arcade oyunu]. Chicago: Midway Games.

Namco. (1980b). Pac-Man [Labirent arcade oyunu]. Chicago: Midway Games.

Nguyen, C. M., Copeland, C. T., Lowe, D. A., Heyanka, D. J. ve Linck, J. F. (2020). Contribution of executive functioning to instrumental activities of daily living in older adults. Applied Neuropsychology: Adult, 27(4), 326-333. https://doi.org/10.1080/23279095.2018.1550408

Nintendo. (1981). Donkey-Kong [arcade oyunu]. Kyoto: Nintendo.

Nintendo. (2005). Brain Age [Bulmaca video oyunu]. Kyoto: Nintendo.

Nintendo DS. (2006). Tetris [Bulmaca video oyunu]. Kyoto: Nintendo.

Nintendo VC. (2006). Super Mario 64 [Platform oyunu]. Kyoto: Nintendo Wii. 
Nouchi, R., Taki, Y., Takeuchi, H., Hashizume, H., Akitsuki, Y., Shigemune, Y., Sekiguchi, A., Kotozaki, Y., Tsukiura, T., Yomogida, Y. ve Kawashima, R. (2012). Brain training game improves executive functions and processing speed in the elderly: A randomized controlled trial. PLOS ONE 7(1): e29676. https://doi.org/10.1371/journal.pone.0029676

Palef, S. R. (1973). Some stages of information processing in a choice reaction time task. Perception \& Psychophysics, 13, 41-44. https://doi.org//10.3758/BF03207232

Perez, M., Izura, C., Stadthagen-Gonzanes, H. ve Marín, J. (2013). Assessment of bilinguals' performance in lexical tasks using reaction times. V. Gathercole (Ed.), Issues in the assessment of bilinguals, içinde (ss. 130-160). Buffalo, NY: Multilingual Matters.

Pliatsikas, C., Veríssimo, J., Babcock, L., Pullman, M. Y., Glei, D. A., Weinstein, M., Goldman, N. ve Ullman, M. T. (2019). Working memory in older adults declines with age, but is modulated by sex and education. Quarterly Journal of Experimental Psychology, 72(6), 1308-1327.

Prakash, R. S., De Leon, A. A., Mourany, L., Lee, H., Voss, M., Boot, W. R., Basak, C., Fabiani, M., Gratton, G. ve Kramer, A. F. (2012). Examining neural correlates of skill acquisition in a complex videogame training program. Frontiers in Human Neuroscience, 6(115). https://doi.org/10.3389/fnhum.2012.00115

Ratcliff, R., Thapar, A. ve McKoon, G. (2006). Aging, practice, and perceptual tasks: A diffusion model analysis. Psychology and Aging, 21(2), 353-371. https://doi.org/10.1037/0882-7974.21.2.353

Rubin, O. ve Meiran, N. (2005). On the origins of the task mixing cost in the cuing task-switching paradigm. Journal of Experimental Psychology: Learning, Memory, and Cognition, 31(6), 14771491. https://doi.org/10.1037/0278-7393.31.6.1477

Salthouse, T. A. (2000). Aging and measures of processing speed. Biological Psychology, 54 (1-3), 3554. https://doi.org/10.1016/S0301-0511(00)00052-1

Sarkar, K., Scanlon, M., Drescher, D. (2007). Lumosity [bilgisayar video oyunu]. San Francisco: Lumos Lab.

Sphere Inc. (1991). Super Tetris. [Bulmaca video oyunu]. Boulder: Spectrum HoloByte.

Stern, Y., Blumen, H. M., Rich, L. W., Richards, A., Herzberg, G. ve Gopher, D. (2011). Space Fortress game training and executive control in older adults: A pilot intervention. Aging, Neuropsychology, and Cognition, 18(6), 653-677. https://doi.org/10.1080/13825585.2011.613450

Stuss, D., Stethem, L., Picton, T., Leech, E. ve Pelchat, G. (1989). Traumatic brain injury, aging and reaction time. Canadian Journal of Neurological Sciences, 16(2), 161-167. https://doi.org/10.1017/ S0317167100028833

Şahin, B. (2019). Yaşlı bireylerde internet kullanımının yaşam doyumu, algılanan sosyal destek ve umutsuzluk düzeyleri ile ilişkisinin incelenmesi (Yüksek lisans tezi). Maltepe Üniversitesi, İstanbul.

Taito. (1981). Qix [Bulmaca arcade oyunu]. Shinjuku: Taito.

Toril, P., Reales, J. M., Mayas, J. ve Ballesteros, S. (2016). Video game training enhances visuospatial working memory and episodic memory in older adults. Frontiers in Human Neuroscience, 10(206). https://doi.org/10.3389/fnhum.2016.00206

Tuncay, F. Ö. ve Fertelli, T. K. (2018). Yaşlılarda bilişsel işlevlerin günlük yaşam aktiviteleri ve yaşam doyumu ile ilişkisi. Dokuz Eylül Üniversitesi Tip Fakültesi Dergisi, 32(3), 190-183. https://doi. org/10.5505/deutfd.2018.82712

Tunçay, N. (2009). FAB (Frontal Assessment Battery) Testinin Türk toplumunda geçerlilik ve güvenilirliği. (Yüksek lisans tezi). İzmir, Türkiye: Dokuz Eylül Üniversitesi.

Uluyol, Ç., Demiralay, R., Şahin, S. ve Eryilmaz, S. (2014). Öğretmen adaylarının oyun tercihleri ve bilgisayar oyunu oynama alışkanlıklarının incelenmesi: Gazi Üniversitesi örneği. Journal of Instructional Technologies and Teacher Education, 3(2). https:/dergipark.org.tr/tr/pub/jitte/ issue/25084/264727 
van Muijden, J., Band, G. P. H. ve Hommel, B. (2012). Online games training aging brains: Limited transfer to cognitive control functions. Frontiers in Human Neuroscience, 6(221). https://doi. org/10.3389/fnhum.2012.00221

Verghese, J., Buschke, H., Viola, L., Katz, M., Hall, C., Kuslansky, G. ve Lipton, R. (2002). Validity of divided attention tasks in predicting falls in older individuals: A preliminary study. Journal of the American Geriatrics Society, 50(9), 1572-1576.

von der Heiden, J. M., Braun, B., Müller, K. W. ve Egloff, B. (2019). The association between video gaming and psychological functioning. Frontiers in Psychology, 10(1731). https://doi.org/10.3389/ fpsyg.2019.01731

West, G. L., Zendel, B. R., Konishi, K., Benady-Chorney, J., Bohbot, V. D., Peretz, I. ve Belleville, S. (2017). Playing Super Mario 64 increases hippocampal grey matter in older adults. PLoS ONE 12(12): e0187779. https://doi.org/10.1371/journal.

Whelan, R. (2008). Effective analysis of reaction time data. The Psychological Record, 58, 475-482. https://doi.org/10.1007/bf03395630

Whitlock, L. A., McLaughlin, A. C. ve Allaire, J. C. (2012). Individual differences in response to cognitive training: Using a multi-modal, attentionally demanding game-based intervention for older adults. Computers in Human Behavior, 28(4), 1091-1096. https://doi.org/10.1016/j. chb.2012.01.012

Yavuz, E. ve Tarlakazan, E. (2018). Üniversite öğrencilerinin mobil oyun profili ve oynama alışkanlıkları. AÇÜ Uluslararası Sosyal Bilimler Dergisi, 4(2), 149-163.

Zelinski, E. M. ve Reyes, R. (2009). Cognitive benefits of computer games for older adults. Gerontechnology: International Journal on the Fundamental Aspects of Technology to Serve the Ageing Society, 8(4), 220-235. https://doi.org/10.4017/gt.2009.08.04.004.00

Zhang S., Grenhart, W. C. M., Sprufera, J. F., McLaughlin, A. C. ve Allaire, J. C. (2019). Using variable priority training to examine video game-related gains in cognition. Journal of Cognitive Enhancement, 4(3), 274-284. https://doi.org/10.1007/s41465-019-00148-1 